\title{
EDITORIAL
}

The Single Market Act relies on a simplified public procurement regime in the European Union, which will result from procedural efficiencies and from streamlining the application of the substantive rules. The professionalization and commercialisation of procurers in the Member States will insert quality and consistency in the public procurement process and assure competitors of legitimate expectations from the award of public contracts. Public procurement regulation will play a pivotal role for the delivery of the European 2020 Growth Strategy.

The European Institutions through the enactment of the Single Market Act ${ }^{1}$ have identified public procurement as an essential component of competitiveness and growth ${ }^{2}$ and as an indispensable instrument of delivering public services. ${ }^{3}$ A generation of legal instruments which aim at establishing gradually a homogenous public procurement market in the European Union were introduced by the recent public procurement Directives. The reforms on public procurement have sought to accomplish unobstructed access to public markets through transparency of expenditure relating to public and utilities procurement, improved market information through the introduction of technology to the application of procurement rules, elimination of technical standards capable of discriminating against potential contractors, uniform application of objective criteria of participation in tendering and award procedures and regulatory alignment between public sector and utilities procurement.

The reforms on public procurement have met three principal objectives: simplification, modernization and flexibility.

The objective of simplification has been met to a large extent by the introduction of the public sector Directive on supplies, works and services which represents a notable example of codification of supranational administrative law. The main influence for the codification of the public sector Directive can be traced in important developments in the application of public procurement rules by defining essential legal concepts such as public contracts, contracting authorities, the remit of selection and qualification criteria, and the parameters for contracting authorities to use environmental and social considerations as award criteria and which have influenced public procurement law making.

The objective of modernization has been met mainly as a result of the newly introduced concepts. The ability of private undertakings, which pursue activities of general interests of non-commercial or industrial character to tender for public contracts alongside bodies governed by public law, the introduction of the competitive dialogue to facilitate the award of complex projects such as public private partnerships and trans-European networks, the introduction of framework procurement to the public sector, the use of electronic procurement concepts such as e-auctions and dynamic purchasing systems, the digitization agenda and the introduction of concessions procurement regulation.

DOI: $10.21552 / \mathrm{epppl} / 2018 / 4 / 3$

1 European Commission, Communication to the European Parliament, the Council, the Economic and Social Committee and the Committee of the Regions, Towards a Single Market Act, COM(2010) 608 final.

2 European Commission, Communication, Europe 2020, A strategy for smart, sustainable and inclusive growth, 3.3.2010, COM (2010) 2020 final.

3 European Commission, Guide to the application of the European Union rules on state aid, public procurement and the internal market to services of general economic interest, and in particular to social services of general interest, 7.12.2010, SEC(2010) 1545 final. European Commission, Buying Social: A Guide to Taking Account of Social Considerations in Public Procurement, SEC(2010) 1258, final. 
The flexibility objective of the public procurement reforms reflects on the relaxation and the disengagement of public procurement rules in industries that operate under genuinely competitive conditions in the utilities sectors, such as telecommunications. Flexibility is also present at the disengagement of the rules in contractual arrangements such as public-public partnerships and in-house relations, as well as in certain sectors, such as water, for concessions procurement.

Future reforms of the public procurement acquis should focus upon the digital transformation of public and utilities procurement. Through the adoption of technology systems such as e-Certis and ESPD, alongside the application of electronic procurement and electronic invoicing, the digitization agenda of public procurement will streamline the application of the rules, introduce efficiency in the process and make public procurement more attractive for businesses, especially SMEs resulting in increased competitiveness.

Another potential for reform should focus on the way service concessions and contracts are awarded by a contracting authority to another contracting authority on the basis of exclusive rights, in the light of the interface of the public procurement acquis with the Services Directive. ${ }^{4}$

Finally, public contracts which fall below the stipulated value thresholds (sub-dimensional contracts) represent a difficult category for future reforms. On the one hand, they encapsulate a significant amount of Member States' public expenditure which escapes the clutches of the public procurement acquis. On the other hand, the European Institutions are keen to subject these contracts to some degree of competition and has supplemented the public procurement Directives with EU law principles which ensure a parallel process of procurement with dimensional public contracts.

The procurement of sub-dimensional contracts has created uncertainty in the market place and resulted in a dysfunctional application of the procurement acquis to those contracts. The administrative and procedural burdens on the part of contracting authorities to subject sub-dimensional contracts to transparency and competitive tendering requirements often surpass any potential efficiency benefits resulting from competitively tendering them. In addition, adequately sufficient safeguards against intentional division of dimensional contracts into lots in order to avoid the applicability of the public procurement Directives do not exist in the current acquis.

The most pronounced deficiency of the public procurement Directives is their porosity which is caused by non-exhaustive harmonisation. The porosity of the public procurement Directives undermines their effectiveness by preventing their applicability to certain contractual situations and as a result restricting a de lege ferenda extension of their provisions.

In order to strengthen the Single Market and as part of the continuous effort to stimulate investment in the EU and its Member States, a policy initiative has been launched to carry out procurement more efficiently through digital technologies and in a sustainable manner from a socio-economic perspective.

The policy package was introduced by the EU Commission on the $3^{\text {rd }}$ of October 2017, where six priority areas have been earmarked for Member States to develop a strategic approach to procurement. The policy initiative on public procurement recognises the importance of soft law to carry the reform agenda of the public procurement acquis. Although EU Member States have benefited from the reform agenda carried by the 2014 Public Pro- 
curement Directives, the need for further simplification and successfully addressing barriers to market is essential in influencing the strategic application of the new rules.

Public Procurement is regarded as an essential lever for the EU 2020 Growth Strategy. For such a lever to impact upon Member States, the modernisation of public administrations is regarded as critical. The introduction of technologies to public procurement, especially information and communication technologies (ICTs) would allow for the efficiency and effectiveness of the regulatory system. Concepts such as end-to-end procurement and interoperable procurement are the result of the digitization agenda which will enhance SME participation and improve cross border procurement.

The soft law package of 2017 includes a number of action priorities such as greater uptake of innovative, green and social criteria in awarding public contracts; professionalization of public buyers; improving access by SMEs to procurement markets in the EU and by EU companies in third countries; increasing transparency, integrity and quality of procurement data; digitisation of procurement processes; and finally more cooperation among public buyers across the EU.

\section{Strategic Procurement}

Strategic procurement in the EU embraces the pivotal importance of the SMEs in achieving economic growth. Public procurement is of utmost economic significance for European SMEs. Although the Public Procurement regime deals effectively with sub-contracting issues, prompt payments and the promotion of SMEs in the selection and qualification procurement phase and the award of public contracts, SMEs across the EU Members States face barriers to accessing public procurement markets and win public contracts. Apart from inherent differences between countries, the value of public contract is one of the major factors that influence the extent to which SMEs can access public contracts. The larger a contract (ie single awards/lots), the less likely it will be awarded to SMEs. Other factors influencing SMEs' share in winning public contracts are the type of contract, the procurement sector, the award procedure and the award criteria.

SMEs account for a considerably lower proportion of above-threshold supplies contracts than that of public works contracts; SMEs play only a marginal role in the supply of commodities, but they accounted to more than three quarters of the contract volume in other procurement sectors; The share of contract volume awarded to SMEs is sensitive to tenders awarded by central government, regional and local authorities and agencies and utilities; SMEs take a much smaller share of the total value of contracts awarded under the various negotiated procedures than under open procedure or restricted procedures. SMEs are not likely to win contracts when the competitive dialogue is utilised; and finally, SMEs are not likely to win contracts when the lowest offer is utilised as award criterion.

\section{Innovative Procurement}

Innovation in the delivery of public services is a priority for procurement regulation and will be achieved through the new procedure of innovation partnerships and the new award criterion of life-cycle costing. Innovation partnerships is an award procedure designed to improve market pull by combining a research contract with a realistic chance to obtain a first purchase if the research result fulfils pre-defined performance levels. Innovation partnerships are structured in successive phases with intermediate targets and payments and cut-off options.

On the other hand, life-cycle costing is an award criterion which covers partly or totally costs over the life cycle of a product, service or works which are borne by the contracting authority or other users, such as costs relating to acquisition, costs of use, such as con- 
sumption of energy and other resources, maintenance costs, end of life costs, such as collection and recycling costs; or costs imputed to environmental externalities linked to the product, service or works during its life cycle, provided their monetary value can be determined and verified; such costs may include the cost of emissions of greenhouse gases and of other pollutant emissions and other climate change mitigation costs.

\section{Responsible Procurement}

Responsible procurement takes into account the socio-economic nature of public service delivery through services of general economic interest and incorporates environmental protection as a component of public procurement regulation.

\section{Digital Procurement}

Efficient procurement promotes systems such as electronic procurement and electronic invoicing which attempt to reduce bureaucracy and costs and allow for a more streamlined process in the delivery of public services. The European Single Procurement Document (ESPD) has been adopted as a formal statement by an economic operator consisting of a self-declaration as preliminary evidence in replacement of certificates issued by public authorities or third parties that the relevant ground for exclusion does not apply and/or that the relevant selection criterion is fulfilled and the relevant information as required by the contracting authority shall be provided upon request by the contracting authority or in the event of the economic operator being the winning bidder.

\section{Cross-border Procurement}

An indicator of the state of functioning of the public procurement acquis is the crossborder procurement volumes which reveal the import penetration of goods, works and services destined for the public sector but originating from a different Member State. Crossborder procurement covers both dimensional procurement (above thresholds) and sub-dimensional procurement (below threshold or low volume procurement). Cross-border procurement proves the level of integration in the relevant market, which indicates a transaction (public contract award) can take place with parties in different parts of the single market. This also reveals the effect of the quality of national public procurement legislation on selection and qualification, award procedures and the elimination of national bias systems such as language, culture, and preferences. 